\title{
Corynespora clerodendrigena sp. nov. causing foliar disease on Clerodendrum viscosum from Sonebhadra forest of Uttar Pradesh, India
}

\author{
Singh $\mathrm{A}^{\mathbf{1}}$, Kumar $\mathrm{S}^{2^{*}}, \operatorname{Singh} \mathrm{R}^{\mathbf{3}}$ and Dubey $\mathrm{NK}^{\mathbf{1}}$ \\ ${ }^{1}$ Center of Advanced Study in Botany, Banaras Hindu University, Varanasi -221005 (U.P.), India. \\ ${ }^{2}$ Birbal Sahni Institute of Palaeobotany, 53, University Road, Lucknow-226007(U.P.), India. \\ ${ }^{3}$ Department of Botany, D.D.U. Gorakhpur University, Gorakhpur-273009 (U.P.), India.
}

Singh A, Kumar S, Singh R, Dubey NK 2013 - Corynespora clerodendrigena sp. nov. causing foliar disease on Clerodendrum viscosum from Sonebhadra forest of Uttar Pradesh, India. Plant Pathology \& Quarantine 3(1), 15-17, doi 10.5943/ppq/3/1/3

Corynespora clerodendrigena sp. nov. is described and illustrated causing foliar disease on Clerodendrum viscosum (Verbenaceae) collected from forests of Sonebhadra, Uttar Pradesh, India.

Key words - Corynespora - foliar disease - Fungal diversity - morphotaxonomy - new species

\author{
Article Information \\ Received 20 February 2013 \\ Accepted 15 March 2013 \\ Published online 15 May 2013 \\ *Corresponding author: Shambhu Kumar - e-mail - skumartaxon@gmail.com
}

\section{Introduction}

During our survey of the forest region of Sonebhadra of District Mirzapur (244ㄴ

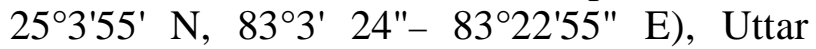
Pradesh, India many specimens showing foliar diseases have been collected. Upon critical morphological examination Corynespora clerodendrigena was found as a novel species and is described here.

\section{Methods}

Surface scrappings and free hand-cut sections were made with a razor blade through infection spots. The material was then mounted in lactophenol cotton-blue mixture for microscopic examination. Detailed observations of morphological characters were carried out using an Olympus CX-31 light microscope with oil immersion $(1000 \times)$. Measurements through micrometry were made of 20 conidia and conidiophores. Line drawings were prepared by camera lucida at a magnification of $1000 \times$. The type specimen was deposited in Herbarium Cryptogamiae Indiae Orientalis (HCIO), Indian Agriculture Research Institute (IARI), New Delhi and an isotype have been retained in the departmental herbarium (Banaras Hindu University (BHU), Herbarium) for further reference. Descriptions and nomenclatural details were deposited in MycoBank (www.Mycobank.org).

\section{Results}

\section{Taxonomy}

Corynespora clerodendrigena Archana Singh, Sham. Kumar, R. Singh \& Dubey sp. nov.

MycoBank MB 801327

Fig. 1

Etymology - clerodendrigena, refers to the plant host, Clerodendrum.

Infection spots amphigenous, subcircular to irregular, forming concentric rings, reddish brown on upper surface and pale reddish brown on lower surface, up to $14 \mathrm{~mm}$ 


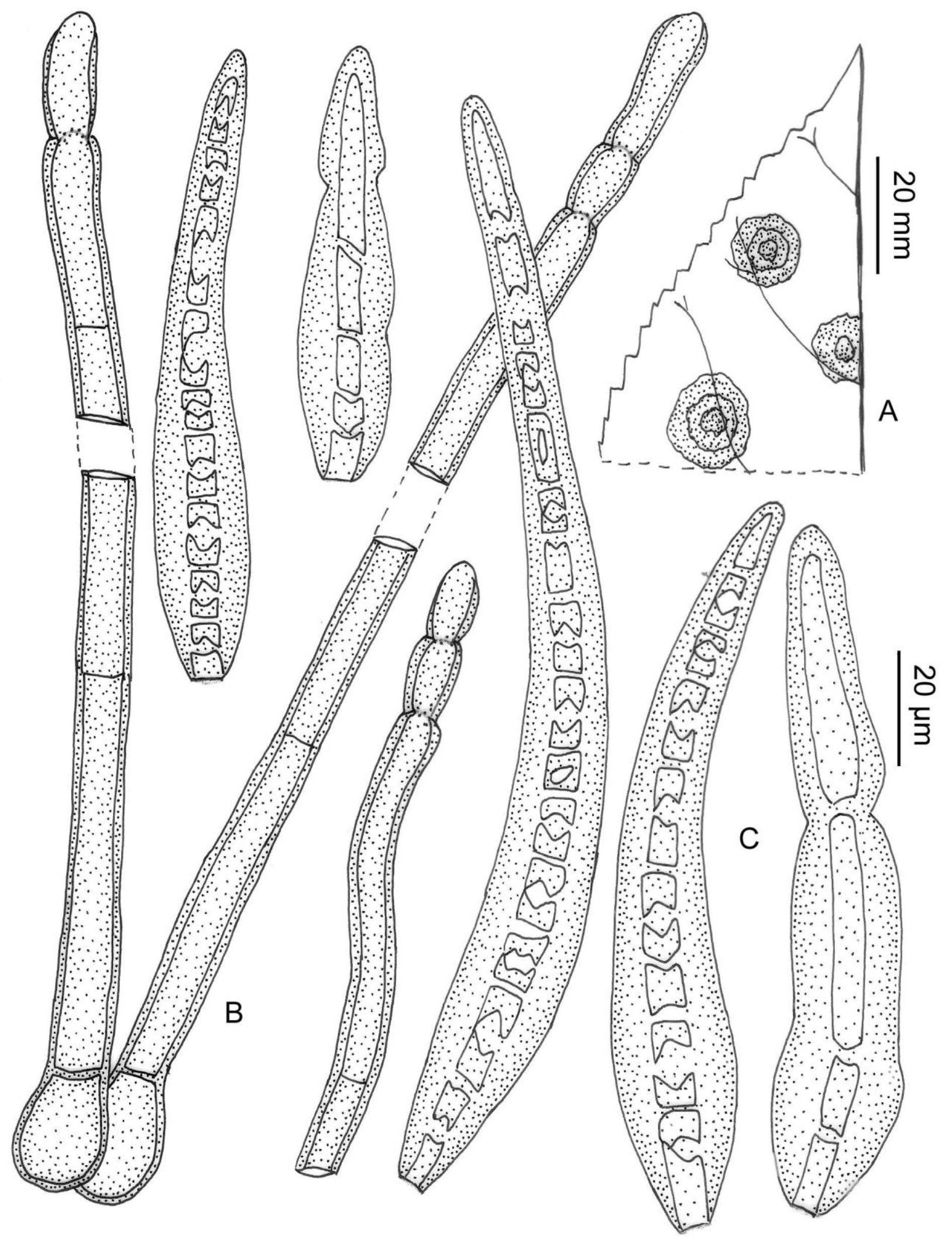

Fig. 1 - Corynespora clerodendrigena. A Infection spots B Conidiophores. C Conidia. Bars A = 20 $\mathrm{mm}, \mathrm{B}-\mathrm{C}=20 \mu \mathrm{m}$. 
in diam. Colonies epiphyllous, effuse. Mycelium internal, composed of branched, septate, thin-walled, smooth, olivaceous to subhyaline hyphae. Stroma absent. Conidiophores macronematous, mononematous, arising singly from hyphae, erect, straight to flexuous, smooth, thick-walled, cylindrical, unbranched or branched, up to 7-septate, 1-10 successive, cylindrical terminal proliferations, brown, 220$720 \times 6-9 \mu \mathrm{m}$. Conidiogenous cells integrated, terminal, monotretic, smooth, cylindrical, swollen towards apex, scars unthickened. Conidia acrogenous, solitary or chain of two conidia, simple, dry, unbranched, thin-walled, smooth, straight to slightly curved, obclavatocylindrical, 3-13-distoseptate, apex obtuse to rounded, base obclavate, light olivaceous, hilum unthickened, $60-220 \times 16-22 \mu \mathrm{m}$.

Material examined - India, Uttar Pradesh, Sonebhadra forest, on living leaves of Clerodendrum viscosum Vent. (Verbenaceae), November 2009, coll. Archana Singh BHU herb No. 9123 (isotype), HCIO 50140 (holotype).

Six species of Corynespora have already been reported on Verbenaceae, viz., $C$. cassiicola (Berk \& M.A. Curtis) C.T. Wei (Wei 1950), C. siwalika (Subram.) M.B. Ellis (Ellis 1961), C. viticus Y.L. Guo (Guo 1984), C. nana Meenu \& Kamal (Meenu \& Kamal 1998), C. catenulata N. Sharma, R.K. Chaudhary \& Kamal (Sharma et al. 2002) and C. clerodendri-viscosi V.K. Pal, M. Akhtar, D.K. Agarwal, R.K. Chaudhary \& N. Ahmad (Pal et al. 2007). Of these, $C$. catenulata and $C$. clerodendri-viscosi were described on the same host genus. However, a comparison with these two earlier reported species shows the novelty of present species.

The conidiophores of $C$. clerodendrigena are approximately twice as long (220-720 $\times 6-9 \mu \mathrm{m})$ than those of $C$. catenulata (62-362 $\times 7-9 \mu \mathrm{m})$ or $C$. clerodendri-viscosi (203-340 $\times 7-10 \mu \mathrm{m})$. The conidiophores have relatively more septa (up to 7) in $C$. clerodendrigena as compared to $C$. catenulata (2-15) and $C$. clerodendri-viscosi (5-10). In addition, the conidiophores show more proliferations (1-10) in C. clerodendrigena than in C. catenulata $(0-$ 9) and in C. clerodendri-viscosi (1-6).
The conidia of $C$. clerodendrigena are longer $(60-220 \times 16-22 \mu \mathrm{m})$ compared to $C$. catenulata $(27.5-225.5 \times 11-19 \mu \mathrm{m})$ and $C$. clerodendri-viscosi $(16-70 \times 6-14 \mu \mathrm{m})$, have more septa (3-13) than in $C$. clerodendriviscosi (1-10) and fewer (1-24) than in $C$. catenulata. The hilum on conidiophores of earlier described species are thickened whereas it is unthickened in $C$. clerodendrigena. Therefore, the present collection is treated as a new species.

\section{Acknowledgements}

Authors are grateful to the Head, Department of Botany, Banaras Hindu University (BHU), Varanasi, Uttar Pradesh, India for providing library and laboratory facilities. Author's thanks are also due to the Curator, HCIO, IARI, New Delhi for depositing the holotype specimens and providing accession numbers thereof. Thanks are also due to Department of Science and Technology, New Delhi for assistance to first author (A. Singh) and Anonymous reviewer for the critical review and useful suggestions to improve the manuscript.

\section{References}

Ellis MB. 1961- Dematiaceous Hyphomycetes III., Mycological Papers 82, 1-55.

Guo YL. 1984 - Four new species of Corynespora. Acta Mycologia Sinica 3, 161-169.

Meenu, Kamal. 1998 - New species of Corynespora. Mycological Research 102, 344-345.

Pal VK, Akhtar M, Agarwal DK, Chaudhary RK, Ahmad N. 2007 - Diversity of foliar fungi in the forest flora of NorthEastern U.P.: five new species of Corynespora Gussow. Indian Phytopathology 60(3), 330-340.

Sharma N, Chaudhary RK, Kamal. 2002 - Five undescribed species of Corynespora. Indian Phytopathology 55(4), 458-463.

Wei CT. 1950 - Note on Corynespora. Mycological Papers 34, 1-9. 